\title{
SPATIAL AND TEMPORAL DIVERSITY OF MACROFUNGI IN THE WESTERN GHAT FORESTS OF INDIA
}

\author{
KARUN, N.C. - SRIDHAR, K.R.* \\ Department of Biosciences, Mangalore University \\ Mangalagangotri, Mangalore 571 199, Karnataka, India \\ *Corresponding author \\ e-mail: kandikere@gmail.com \\ (phone: +91-824-2287-261; fax: +91-824-2287-367) \\ (Received $1^{\text {st }}$ Feb 2015; accepted $23^{\text {rd }}$ Jan 2016)
}

\begin{abstract}
This study presents results of macrofungal inventory in the Western Ghat forest of Karnataka (reserve forest, shola forest, sacred grove and coffee agroforest) during wet season (June-November). A total of 157 species belonging to 87 genera was recovered. A maximum of 53 species was found in the coffee agroforest with highest diversity, exclusive (confined to a specific forest: $42 \mathrm{sp}$.) and core-group (frequency of occurrence, $\geq 10 \%: 17 \mathrm{sp}$.) species. Irrespective of forest, the species richness attained peaks during June and September. Rarefaction indices of species against sporocarps also showed the highest expected number of species in coffee agroforest. Of a total of 9256 sporocarps, the coffee agroforest consists of highest sporocarps than other forests (3715 vs. 1676-2999). Two-way ANOVA revealed significant spatial difference in richness of species $(P<0.01)$ as well as sporocarps $(P<0.05)$ without significant difference temporally. Low species similarity among forests surveyed (2.4-8.5\%) depicts uniqueness of macrofungi in these forests. This survey yielded 45 new records to the Western Ghats and 47 economically valuable core-group fungi (edible, medicinal and ectomycorrhizal). Maintenance of suitable edaphic conditions along with enrichment organic matter (woody and leaf litter) in coffee agroforests seems to maximize economically viable macrofungi.
\end{abstract}

Keywords: diversity, forests, macrofungi, mushrooms, Western Ghats

\section{Introduction}

Fungi constitute one of the widely distributed biological entities involved mainly in decomposition of organic matter, biogeochemical cycles, mutualistic associations and pathogenicity (Kendrick, 2000). A conservative global estimate of fungi ranges between 1.5 and 3 million species (Hawksworth, 2001, 2012) and macrofungi has worldwide distribution ranging from 53,000 to 110,000 species based on the ratio of plant/macrofungi (Mueller et al., 2007). Forest ecosystems in Himalayan and the Western Ghat ranges of India are the major hotspots of fungal diversity consisting of about 850 species of macrofungi (Manoharachary et al., 2006).

The Western Ghats of India is a stretch of 1,600 km mountain range distributed in $160,000 \mathrm{~km}^{2}$ in six political States (Gujarat, Maharashtra, Goa, Karnataka, Tamil Nadu and Kerala). The Western Ghats in Karnataka State endowed with a wide range of vegetation (grasslands, shola forests, deciduous forests, moist-dry deciduous forests, evergreen forests, semi-evergreen forests and scrub jungles) at different altitudinal ranges ( $\sim 500$ to $1,200 \mathrm{~m}$ asl). Although a variety of macrofungi have been reported from the Western Ghats, investigations in Karnataka are sporadic and quantitative studies are meager (e.g. Natarajan et al., 2005a; Brown et al., 2006; Swapna et al., 2008; Karun and Sridhar, 2013, 2014; Karun et al., 2014). Moreover, there is a gap in temporal assessment of macrofungi in the forests of Western Ghat. Therefore, the 
present inventory compares the occurrence of macrofungi in three natural forests (reserve forest, shola forest and sacred grove) and one agroforest (coffee agroforest) in the Western Ghats to draw insight on their diversity and temporal distribution pattern.

\section{Materials and methods}

\section{Study area and survey}

The forests surveyed for macrofungi include Makutta reserve forest in Perambadi $\left(12^{\circ} 8 ' \mathrm{~N}, 75^{\circ} 47^{\prime} \mathrm{E} ; 897 \mathrm{~m}\right.$ asl), Monnangeri shola forest in Sampaje $\left(12^{\circ} 28^{\prime} \mathrm{N}, 75^{\circ} 37^{\prime} \mathrm{E} ; 608\right.$ $\mathrm{m}$ asl), Kadnur sacred grove in Virajpet $\left(12^{\circ} 13^{\prime} \mathrm{N}, 75^{\circ} 46^{\prime} \mathrm{E}\right.$; $891 \mathrm{~m}$ asl) and coffee agroforest in B'Shettigeri (12 ${ }^{\circ} 7^{\prime} \mathrm{N}, 75^{\circ} 52^{\prime} \mathrm{E}$; $846 \mathrm{~m}$ asl) located in Kodagu District of Karnataka State (Figure 1). The survey was carried out throughout the wet season on monthly basis during monsoon (June-September 2012) and post-monsoon (October-November 2012) seasons. The rainfall data in each forest was recorded from the nearest meteorological observatory and it was highest in reserve forest $(533.4 \mathrm{~cm})$ followed by shola forest $(482.6 \mathrm{~cm})$, coffee agroforest $(419.1 \mathrm{~cm})$ and sacred grove $(393.7 \mathrm{~cm})$. Among the forests studied, coffee agroforest is fragmented owing to plantation practices.

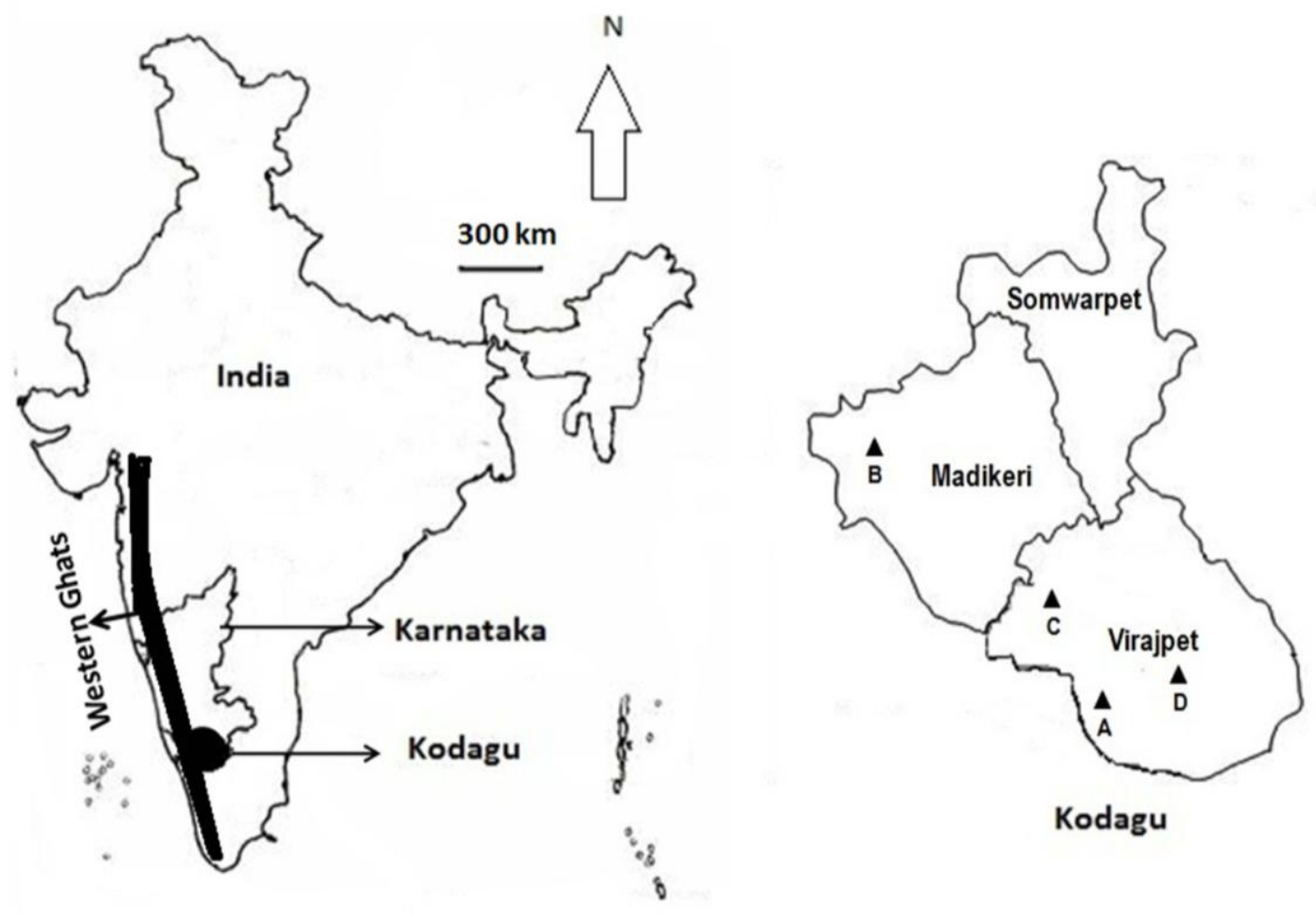

Figure 1. Map of the study area in Kodagu District of the Western Ghats: A, Makutta reserve forest near Perambadi; B, Monnangeri shola forest near Sampaje; C, Kadnur sacred grove near Virajpet; $D$, B 'Shettigeri coffee agroforest near Ponnampet.

In each forest, macrofungal assessment was carried out on monthly basis during wet season in one quadrat $(25 \times 25 \mathrm{~m})$ without overlapping. Qualitative and quantitative assessment of sporocarps of macrofungi occurring on soil, leaf litter, woody litter, 
standing dead or live trees (bark or branches) and other substrates (e.g. dung and dead insects) was carried out. Macromorphological characteristics of representative species of macrofungi sampled were assessed on the sampling site, blotted and preserved in ziploc bags in cool packs for further assessment. Microscopic observation was carried out in the laboratory (Olympus \# CX41RF; magnification, 1000X) using diagnostic keys to confirm the identity (Jordan, 2004; Phillips, 2006; Sathe and Daniel, 1980; Sathe and Deshpande, 1980; Tibuhwa et al., 2010; Mohanan, 2011; Buczacki, 2012; Tibuhwa, 2012). Blotted representative specimen were preserved by transferring into a preservative (water-ethanol-formaldehyde: 14:5:1) and additional blotted mushrooms were oven-dried $\left(55-60^{\circ} \mathrm{C}\right)$ and preserved in ziploc bags.

\section{Data analysis}

The mean number of sporocarps of each macrofungus/quadrat in each forest (MSF) ( $n=$ 6; in six months; irrespective of months) as well as mean number of sporocarps of each macrofungus/quadrat in each month (MSM) $(n=4$; in four forests; irrespective of forests) were plotted along with overall mean number of sporocarps/quadrat (MS) $(n=24)$.

$$
\begin{gathered}
M S F=(T S L \div T Q) \\
M S M=(T S M \div T Q) \\
M S=(T S \div T Q)
\end{gathered}
$$

(where, MSF, mean sporocarps of a species/forest/quadrat; TSL, total sporocarps of a species in a forest; TQ, total number of quadrats surveyed; MSM, mean sporocarps of a species/month/quadrat; TSM, total sporocarps of a species/month; MS, mean sporocarps of a species/quadrat; TS, total sporocarps of a species). Those macrofungi having $\geq 10 \%$ frequency of occurrence was considered as core-group fungi.

The Simpson $\left(D^{\prime}\right)$ and Shannon $\left(H^{\prime}\right)$ index (Magurran 1988) and Pielou's evenness $\left(J^{\prime}\right)$ (Pielou 1975) of macrofungi in different forests and months were calculated:

$$
\begin{gathered}
D^{\prime}=1 \div \sum(p i)^{2} \\
H^{\prime}=-\sum\left(p_{i} \ln p_{i}\right) \\
J^{\prime}=\left(H^{\prime} \div H_{\text {max }}^{\prime}\right)
\end{gathered}
$$

(where, $p_{i}$ is the proportions of sporocarps that species $i$ contributes to the total number of sporocarps of all species; $H_{\text {max }}^{\prime}$ is the maximum value of diversity for the number of species present)

Sorensen's similarity coefficient $(\%)$ of macrofungi between different forests and months was determined based on Chao et al. (2005): 


$$
C_{\mathrm{S}}=[(2 c) \div(a+b)] \times 100
$$

(where, $a$ is total number of species in forest or month $1 ; b$ is total number of species in forest or month 2; $c$ is number of species common to forest or month 1 and 2).

To compare the richness of species based on the number of sporocarps in each forest or month, the expected number of species $\left[E_{\mathrm{s}}\right]$ was calculated using rarefaction index by Ludwig and Reynolds (1988). The $E_{\mathrm{s}}$ in a random sample of $n$ sporocarps from a grand total of $N$ sporocarps was estimated:

$$
E_{\mathrm{s}}=\sum_{i=1}^{s}\left\{1-\left[\left(\begin{array}{c}
N-n_{i} \\
n
\end{array}\right) /\left(\begin{array}{l}
N \\
n
\end{array}\right)\right]\right\}
$$

(where, $n_{i}$ is the number of sporocarps of the $i$ th species).

Two-way ANOVA was employed to ascertain spatial (forest) and temporal (month) impact on the richness of species and sporocarps of macrofungi by multiple comparisons using Holm-Sidak method (SigmaPlot, version 11, Systat Inc., USA).

\section{Results}

\section{Forest and season}

The present inventory revealed occurrence of 157 species of macrofungi in 87 genera encompassing 45 new records of macrofungi to the Western Ghats consisting of 16 and 29 species identified up to species and genus level, respectively (Appendix 1). Some of the representative species of macrofungi are projected in Figure 2 and Figure 3. Among the four forests surveyed, irrespective of seasons, the highest number of macrofungi (53 vs. 37-42 species) (Figure 4A), exclusive species (those confined to a specific forest: 42 vs. 33-35 species) and core-group species (17 vs. 6-11 species) were highest in coffee agroforest (Figure 4B). Based on the rarefaction indices out of 625 random number of sporocarps, the expected number of species was also higher in the coffee agroforest than in other forests (45 vs. 31-37 species) (Table 1). The Simpson and Shannon indexes were peaked in the coffee agroforest. The Sorensen similarity coefficient showed low overlapping in different forests ranging from $2.4 \%$ (reserve forest $v s$. shola forest) to $8.5 \%$ (sacred grove vs. coffee agroforest) depicting uniqueness of macrofungi in these forests (Table 2). The trend was also same in different forests as reflected in the rarefaction curves (Figure 5A). Similar to species richness, the sporocarp richness was highest in coffee agroforest (3715) followed by shola forest (2999) (Figure 6A).

Irrespective of forests, seasonal survey for six months revealed two peaks in species richness (June and September) (Figure 4C). Overall, the monsoon season (JuneSeptember) consists of higher species richness compared to post-monsoon season (October-November). The exclusive species were steeply declined, while the core-group species were highest during September (Figure 4D). The rarefaction index out of 625 random number of sporocarps revealed the highest expected number of species during June (42 species) followed by September (41) (Table 1). The Simpson index was also 
highest in June/July, while the Shannon diversity was highest during September. The Sorensen's similarity coefficient in different months ranged between $2.5 \%$ (June vs. October) and 55.6\% (October vs. November) (Table 2). The Sorensen's similarity coefficient between consecutive months was steadily increased from June to November (Figure 5B). Similar to species richness, the sporocarp richness was also highest during September followed by August (Figure 6B).

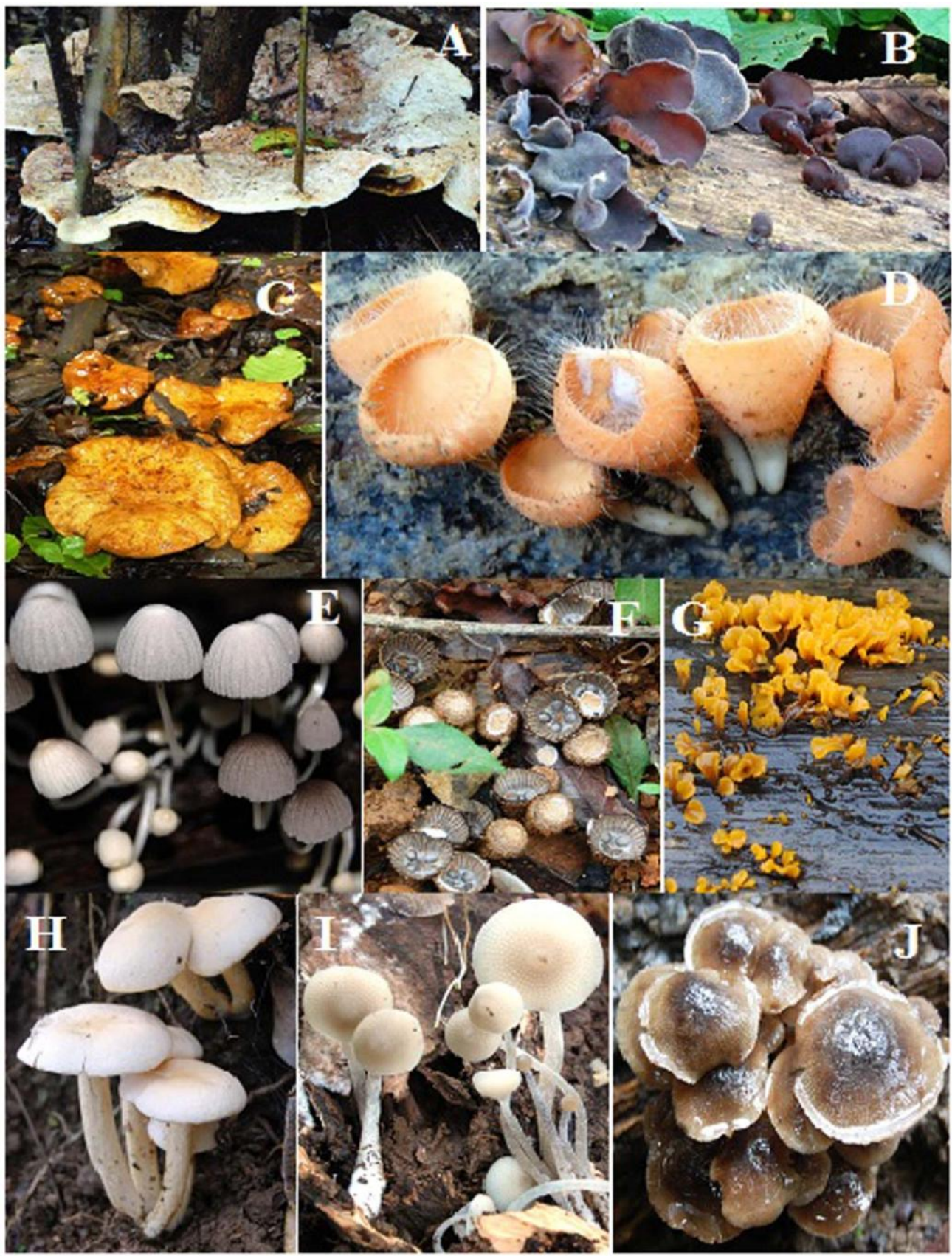

Figure 2. Sporocarps of selected core-group fungi: A, Amylosporus campbellii (edible); B, Auricularia auricula-judae (edible); $C$, Boletinellus merulioides (edible and ectomycorrhizal);

$D$, Cookeina tricholoma; E, Coprinus disseminates (edible); F, Cyathus striatus; $G$,

Dacryopinax spathularia; H, Entoloma theekshnagandhum (ectomycorrhizal); I and J, Immature and mature Filoboletus manipularis (edible). 


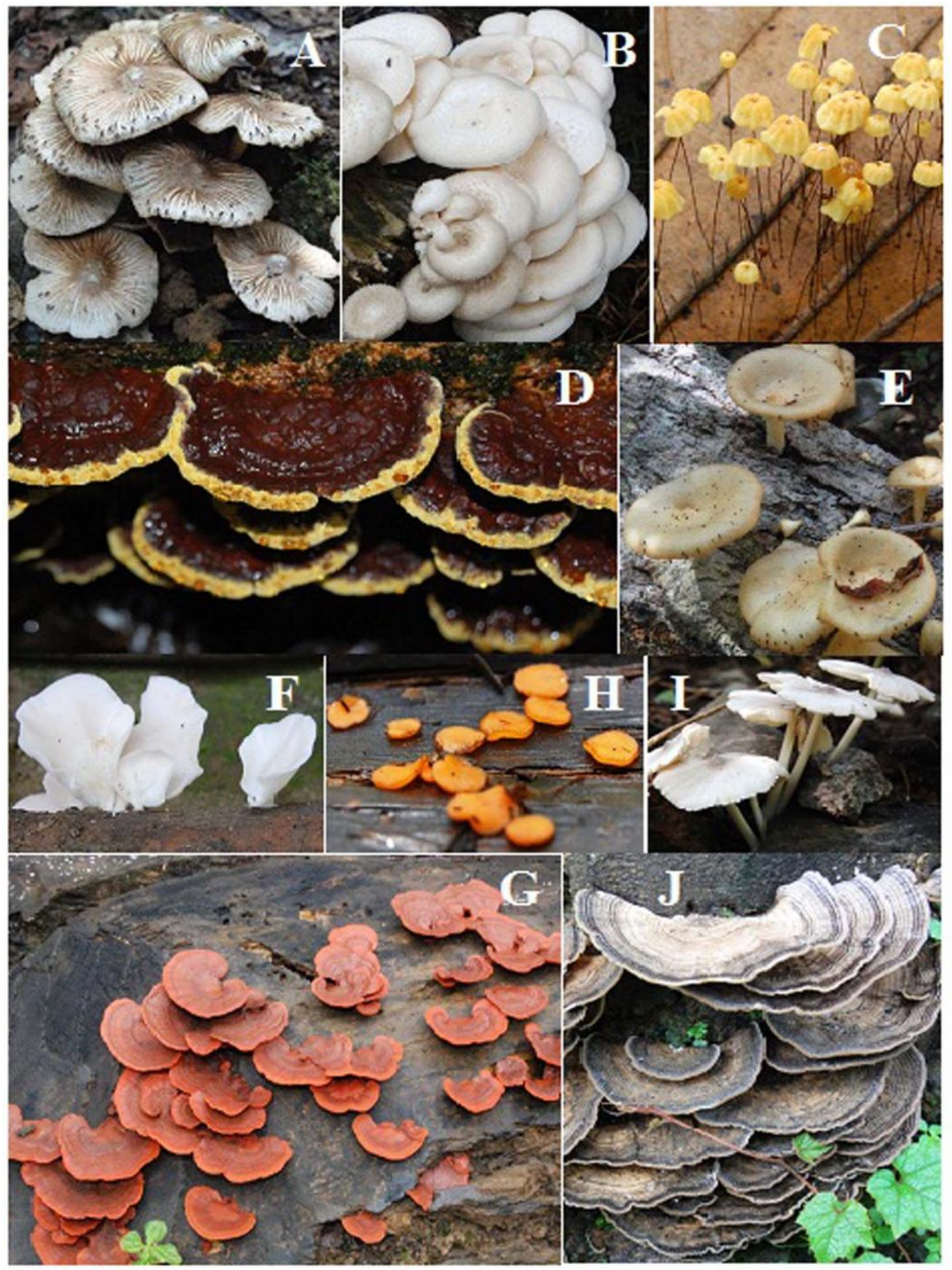

Figure 3. Sporocarps of selected core-group fungi: A, Inocybe viridiumbonata (ectomycorrhizal); B, Lentinus squarrosulus (edible); C, Marasmius guyanensis; D, Phellinus gilvus (medicinal); E, Pleurotus cornucopiae (edible); F, Pleurotus djamor (edible); $G$, Pycnoporus cinnabarinus (medicinal); H, Scutellinia setosa; I, Termitomyces microcarpus (edible) and $\mathrm{J}$, Trametes versicolor (medicinal). 

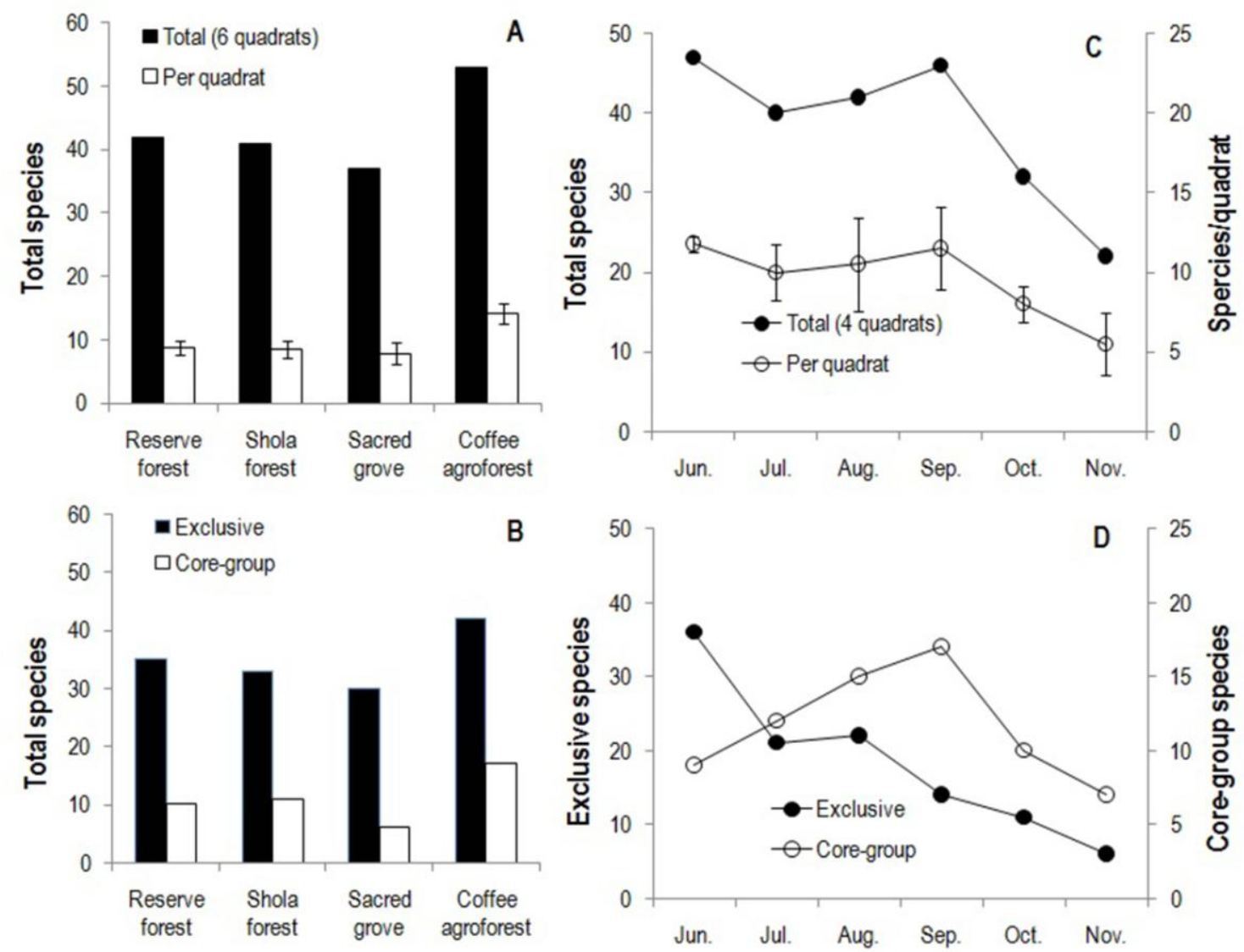

Figure 4. Total species, species/quadrat, exclusive species and core-group species in different forests $(A, B)$ and months $(C, D)$ (species/quadrat in forest, $A: n=6$, mean $\pm S E$; species/quadrat in months, $C: n=4$, mean $\pm S E$ ).

Table 1. Species richness, diversity and evenness of macrofungi in different forests and months of the Western Ghats (*Expected number of species, Es, out of 625 random number of sporocarps)

\begin{tabular}{llllll}
\hline & \multicolumn{2}{l}{ Species richness } & \multicolumn{2}{l}{ Diversity index } & Pielou's \\
& Total species & $E_{(s 625)^{*}}$ & Simpson & Shannon & evenness \\
\hline Forest & & & & & \\
$\quad$ Reserve forest & 42 & 37 & 0.928 & 4.349 & 0.806 \\
Shola forest & 42 & 36 & 0.868 & 3.685 & 0.683 \\
Sacred grove & 36 & 31 & 0.804 & 3.056 & 0.591 \\
Coffee agroforest & 53 & 45 & 0.939 & 4.576 & 0.799 \\
\hline Month & & & & & \\
June & 47 & 42 & 0.934 & 4.044 & 0.728 \\
July & 40 & 37 & 0.934 & 4.355 & 0.818 \\
August & 42 & 35 & 0.881 & 3.843 & 0.713 \\
September & 46 & 41 & 0.933 & 4.504 & 0.815 \\
October & 32 & 31 & 0.907 & 4.065 & 0.813 \\
November & 22 & 22 & 0.929 & 4.078 & 0.914 \\
\hline
\end{tabular}




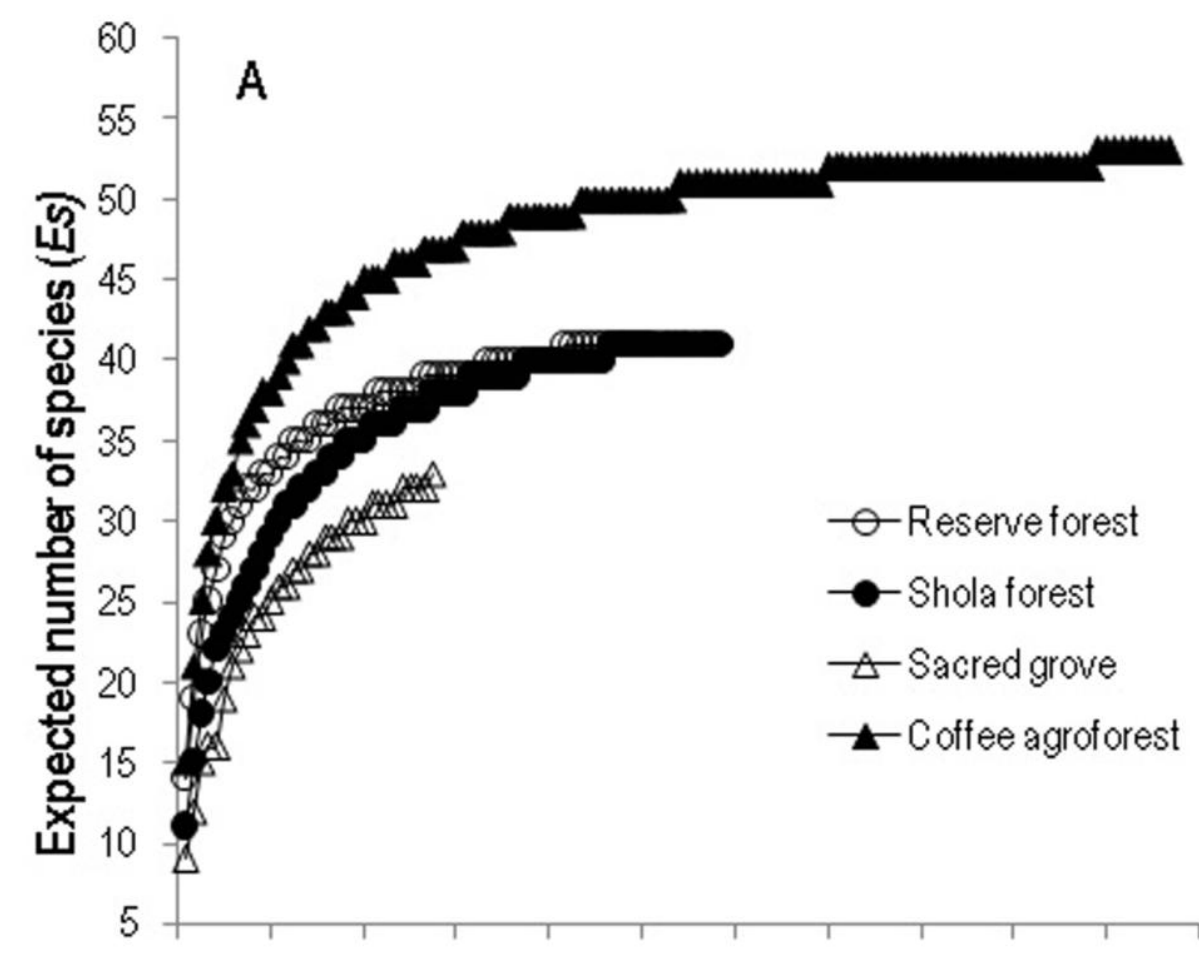

$0 \quad 300 \quad 600 \quad 90012001500180021002400270030003300$

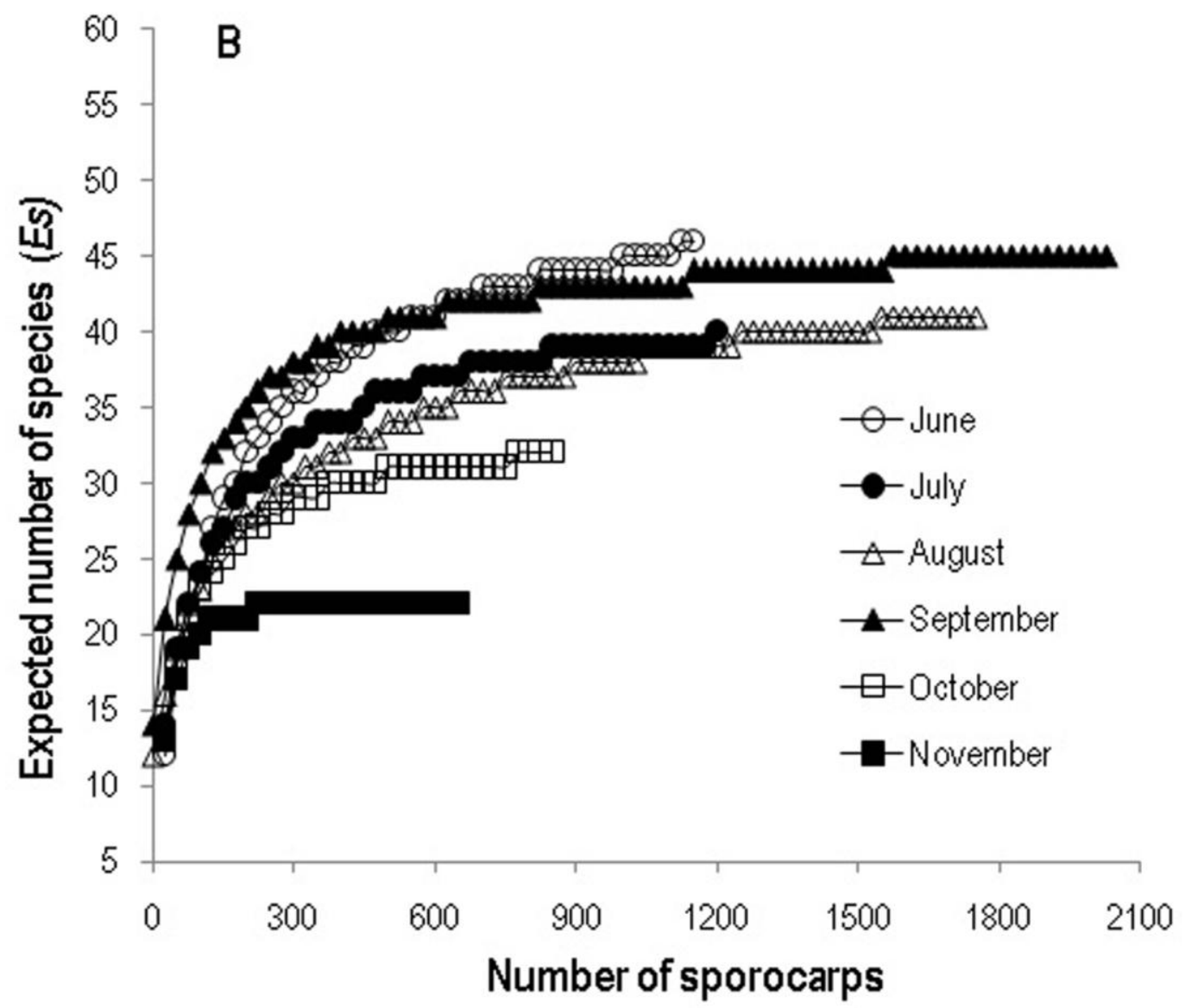

Figure 5. Rarefaction curves of macrofungal expected number of species [Es] against the number of sporocarps in different forest $(A)$ and months $(B)$. 

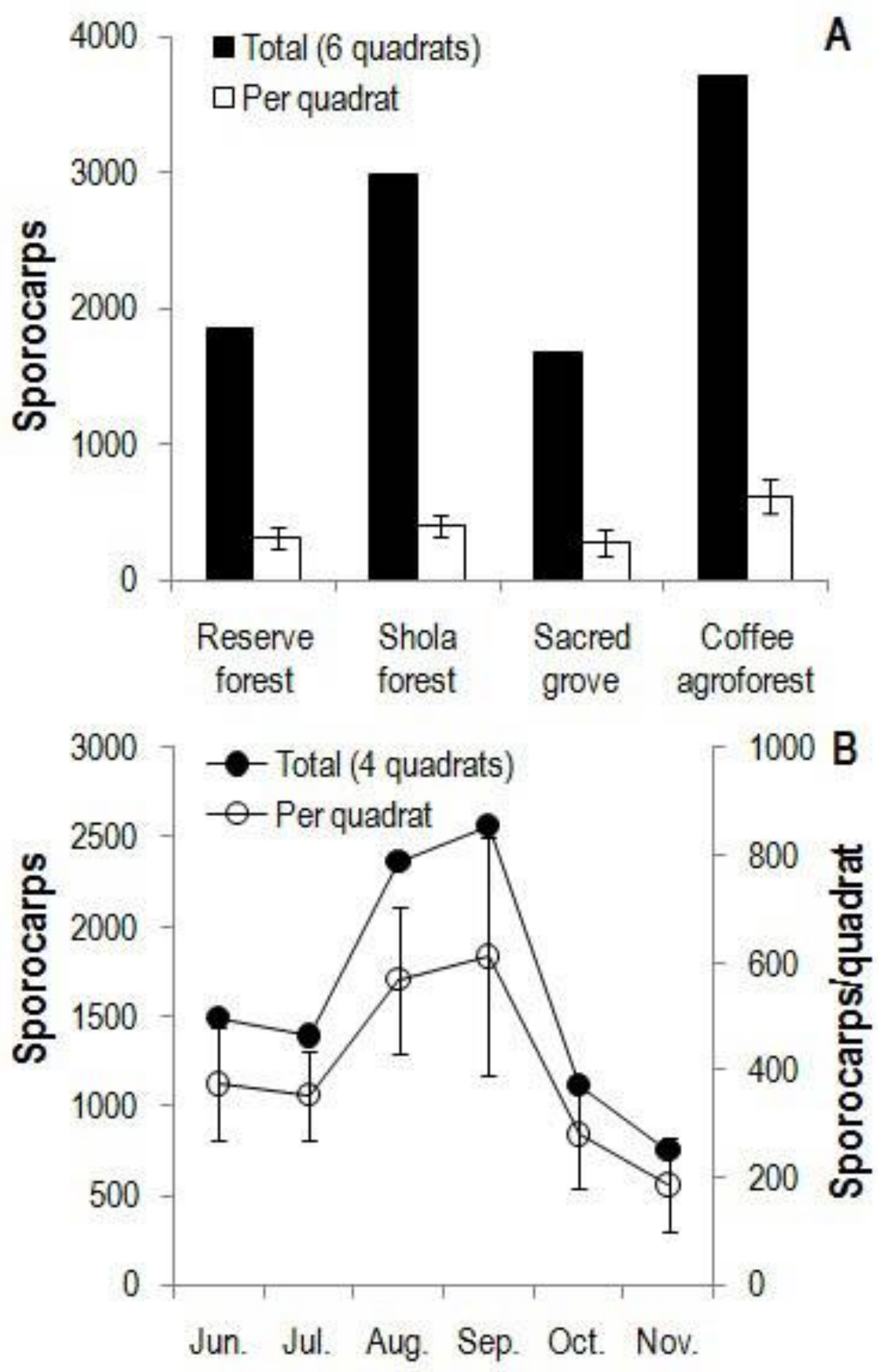

Figure 6. Total sporocarps, and sporocarps/quadrat in different forests $(A)$ and months $(B)$ (sporocarps/quadrat in forest, $A$ : $n=6$, mean $\pm S E$; sporocarps/quadrat in months, $B: n=4$, mean $\pm S E)$. 
Table 2. Sorensen's similarity coefficient (\%) of macrofungi in four forests (RF, Reserve forest; SF, Shola forest; SG, Sacred grove; CAF, Coffee agroforest) during six months (Monsoon: June-September; post-monsoon: October-November) in the Western Ghats

\begin{tabular}{|c|c|c|c|c|c|c|c|c|c|}
\hline \multicolumn{4}{|c|}{ Forest } & \multicolumn{6}{|c|}{ Month } \\
\hline & SF & SG & CAF & & Jul. & Aug. & Sep. & Oct. & Nov. \\
\hline \multirow[t]{5}{*}{$\mathrm{RF}$} & 2.4 & 5.1 & 8.4 & Jun. & 9.2 & 9.0 & 10.8 & 2.5 & 2.9 \\
\hline & SF & 7.7 & 8.5 & & Jul. & 26.8 & 27.9 & 11.1 & 12.9 \\
\hline & & SG & 6.7 & & & Aug. & 29.6 & 13.5 & 12.5 \\
\hline & & & & & & & Sept. & 38.5 & 29.4 \\
\hline & & & & & & & & Oct. & 55.6 \\
\hline
\end{tabular}

Two-way ANOVA revealed significant difference in overall species richness $(\mathrm{P}<0.01)$ and overall sporocarp richness $(P<0.05)$ among different forests but not among different months. Holm-Sidak multiple comparisons resulted in significant difference in the species richness between coffee agroforest $v s$. other forests (shola forest, $P<0.001$; reserve forest, $P<0.01$; sacred grove, $P<0.01$ ).

\section{Core-group fungi and substrate preference}

The core-group fungi have a major role to play in the ecosystem services compared to those occur in low frequency. Among 157 species of macrofungi, 47 belonged to core-group (Appendix 1) and $43 \%$ of species possess economic importance (edible, 25 species; medicinal, 25 species; ectomycorrhizal, 17 species). Besides saprophytes, up to $50 \%$ of core-group fungi are economically valuable (edible, 11 species; medicinal, 11 species; ectomycorrhizal, 3 species). Nine core-group fungi are new records for the Western Ghats (Ganoderma oregonense, Marasmiellus ramealis, Marasmius guyanensis, $M$. pellucidus, Ophiocordyceps nutans, Phellinus pini, Pleurotus cornucopiae, Pluteus sp. 2 and Xylaria filiformis) and some are likely to be new species or varieties. Among the core-group fungi, edible species were higher in shola forest followed by coffee agroforest than other forests ( $5 \mathrm{spp}$. vs. $1 \mathrm{sp}$.). The core-group fungi were recorded on different substrates like bark, dead insects, leaf litter, soil, twigs and wood (Appendix 1). Majority of them preferred woody litter (bark, twig and wood) $(83 \%)$, the rest confined to soil/elephant dung (13\%) and leaf litter/dead insects (4\%). Although six species of macrofungi were confined to the elephant dung, none belongs to core-group category.

\section{Discussion}

Even though some studies are available on the diversity, taxonomy and distribution of macrofungi in the Western Ghats (e.g. Farook et al., 2013; Sathe and Daniel, 1980; Sathe and Deshpande, 1980; Mohanan, 2011), quantitative studies are scanty (e.g. Natarajan et al., 2005a, 2005b; Brown et al., 2006; Swapna et al., 2008). Bhagwat et al. (2005) and Brown et al. (2006) surveyed reserve forests, sacred groves and coffee plantations distributed in different parts of the Western Ghats. 
They sampled macrofungi in three occasions during monsoon (May-September) and recorded 163 species. Similarly, Swapna et al. (2008) surveyed several sampling stations of semi-evergreen and moist deciduous forests of the Western Ghats up to two years and reported 315 species. Surprisingly, even though less area as well as a few forest types were surveyed, 157 species were recorded in our study. As the similarity coefficient between consecutive months was steadily increased from June through November, overlapping species was lower during monsoon than in postmonsoon as supported by the rarefaction index. Overall, two peaks in species richness (June and September) coincided with peaks of exclusive species (June), core-group species (September) and sporocarp richness (September). A sudden change due to the onset of south-west monsoon in May and stability of edaphic factors during September in the Western Ghats might be plausible reasons for peaks in species as well as sporocarps in forests surveyed.

According to Brown et al. (2006), among the three forests (reserve forests, sacred groves and coffee plantations), the sacred groves possess the highest species as well as sprorcarps. In coffee plantations in their study, although species and sporocarp richness were low, Shannon index was higher than reserve forests and sacred groves. On the contrary, the coffee agroforest in our study revealed higher richness of species as well as sporocarps compared to other forests although samples and periodicity of survey was uniform. This has also been supported by the two-way ANOVA with significant difference in species richness between coffee agroforest against other forests. As the species similarity was low among the forests surveyed, it can be predicted that macrofungi existing in these forests are fairly unique. Likewise, the evergreen forests of the Western Ghats showed uniqueness in macrofungi as reported by Brown et al. (2006) and Swapna et al. (2008).

Brown et al. (2006) also opined that the degradation of habitat is a major threat for diversity of macrofungi than the habitat fragmentation. However, in spite of human interference and fragmentation, the coffee agroforest showed highest species richness as well as diversity possibly due to prevalence of suitable edaphic conditions (e.g. moisture and temperature) and deposition of substrates (e.g. woody and leaf litter) on the floor. The standing dead wood, leaf and woody litter accumulated on the forest floor are valuable lignocellulosic materials in maintaining suitable conditions for the growth and perpetuation of macrofungi (Hammel, 1997).

Bhagwat et al. (2005) recorded negligible occurrence of entomophagus and coprophilous macrofungi in reserve forests, sacred groves and coffee plantations $(1.8-3.8 \%)$ corroborating our study $(4.5 \%)$. Edible macrofungi were relatively more in sacred groves than in reserve forests and coffee plantations (Bhagwat et al., 2005). Out of a total of 163 species reported by Bhagwat et al. (2005), only one species belonged to Termitomyces. Similarly, out of 315 species reported in semi-evergreen and moist deciduous forests, none of them belonged to Termitomyces (Swapna et al., 2008). Surprisingly, our study revealed occurrence of five species of Termitomyces ( $T$. clypeatus, T. eurrhizus, T. heimii T. microcarpus and T. tylerianus) and T. microcarpus was core-group species in shola forest as well as coffee agroforest.

Macrofungal species composition vary at altitudinal ranges and between the habitats of the Western Ghats (e.g. evergreen, semi-evergreen, moist deciduous and deciduous forests), which is depending on the tree species, substrate availability (quality, quantity and season), surface area and penetration of sunlight (Bhagwat et al., 2005; Brown et al., 2006). Brown et al. (2006) surveyed representative locations in the reserve forests, 
sacred groves and coffee plantations of entire Kodagu District. Swapna et al. (2008) confined their inventory to the semi-evergreen and moist deciduous forests of Shimoga District. Natarajan et al. (2005a) surveyed the Nilgiri Biosphere Reserve forest spread over in three States of the Western Ghats (Tamil Nadu, Kerala and Karnataka). Another study by Natarajan et al. (2005b) mainly focused on the occurrence of ectomycorrhizal fungi in forest dominated by dipterocarp tree species (Dipterocarpus indicus, Hopea parviflora and Vateria indica) in the Uppangala forest region of Kodagu. The above studies corroborates with the present survey with low overlap of species between the forests of different geographical regions predicting uniqueness of macrofungi.

\section{Conclusions}

Inventory of macrofungi in four forest types in the Western Ghats of India up to six months during wet season yielded 157 species in 87 genera. Low species similarity among forests (2.4-8.5\%) depicts uniqueness of macrofungi possibly due to prevelance of forest-specific edaphic conditions. Coffee agroforest showed the highest species richness, sporocarp richness and diversity of macrofungi. Irrespective of the forest type, June and September showed peaks in species as well as sporocarp richness. Out of 47 core-group fungi, up to $50 \%$ species was economically viable (edible, medicinal and ectomycorrhizal) preferred woody litter. It is predicted that maintenance of coffee agroforest surveyed in the Western Ghats with diverse tree species, edaphic conditions (e.g. temperature, moisture and humidity) and ample substrates on the floor favoured perpetuation of economically viable macrofungi. Blending traditional knowledge of tribals on macrofungi in different forests of the Western Ghats and enforcing modern agricultural practices in agroforestry in favour of macrofungi will facilitate sustainable production for future benefits.

Acknowledgements. The authors are grateful to Mangalore University for permission to carry out this study in the Department of Biosciences. NCK acknowledges Mangalore University for partial financial support through fellowship under the "Promotion of University research and scientific excellence" (PURSE), Department of Science Technology, New Delhi. KRS acknowledges the award of UGC-BSR Faculty Fellowship by the University Grants Commission, New Delhi (Grant \# F.18-1(64)/2014(BSR). We are indebted to Mr. Padiyanda Santhosh Subramani and Mr. Kumbera Prajwal Poovaiah for field assistance during the survey. We are thankful to Mr. Keshavachandra, Department of Applied Botany, Dr. Ambarish C. Nair, Department of Biochemistry and Mr. Sudeep D. Ghate, Department of Biosciences Mangalore University for their timely help and suggestions. We highly appreciate reasonable comments by the referees to improve presentation of this paper.

\section{REFERENCES}

[1] Bhagwat, S., Kushalappa, C., Williams, P., Brown, N. (2005): The role of informal protected areas in maintaining biodiversity in the Western Ghats of India. - Ecology and Society 10: 8, http://www.ecologyandsociety.org/vol10/iss1/art8/

[2] Brown, N., Bhagwat, S., Watkinson, S. (2006): Macrofungal diversity in fragmented and disturbed forests of the Western Ghats of India. - Journal of Applied Ecology 43: 11-17.

[3] Buczacki, S. (2012): Collins Fungi Guide. - Harper-Collins Publishers, London.

[4] Chao, A., Chazdon, R.L., Colwell, R.K., Shen, T.J. (2005): A new statistical approach for assessing similarity of species composition with incidence and abundance data. - Ecology Letters 8: 148-159. 
[5] Farook, V.A., Khan, S.S., Manimohan, P. (2013): A checklist of agarics (gilled mushrooms) of Kerala State, India. - Mycosphere 4: 97-131.

[6] Hawksworth, D.L. (2001):The magnitude of fungal diversity: The 1.5 million species estimate revisited. - Mycological Research 105: 1422-1432.

[7] Hawksworth, D.L. (2012): Global species numbers of fungi: Are tropical studies and molecular approaches contributing to a more robust estimate? - Biodiversity and Conservation 21: 2425-2433.

[8] Hammel, K.E. (1997): Fungal degradatioin of lignin. - In: Cadisch, G., Giller, K.E. (ed.) Driven by Nature: Plant Litter Quality and Decomposition. CAB International, UK.

[9] Jordan, M. (2004): The Encyclopedia of Fungi of Britain and Europe. - Francis Lincoln Publishers Ltd., London.

[10] Karun, N.C., Sridhar, K.R. (2013): On the occurrence and distribution of Termitomyces (Basidiomycota, Agaricales) in the Western Ghats and on the west coast of India. Czech Mycology 65: 233-254.

[11] Karun, N.C., Sridhar, K.R., Appaiah, K.A.A. (2014): Diversity and distribution of macrofungi in Kodagu region (Western Ghats): A preliminary account. - In: Pullaiah, T. (ed.) Biodiversity in India, Volume \# 7. pp. 73-96. Regency Publications, New Delhi.

[12] Karun, N.C., Sridhar, K.R. (2014): Geasters in the Western Ghats and west coast of India. - Acta Mycologica 49: 207-219.

[13] Kendrick, B. (2000): The Fifth Kingdom (3rd Edition). - Mycologue Publications, Canada.

[14] Ludwig, J.A., Reynolds, J.F. (1988): Statistical Ecology: A Primer on Methods and Computing. - Wiley. New York.

[15] Magurran, A.E. (1988): Ecological Diversity and its Measurement. - Princeton University Press, New Jersey.

[16] Manoharachary, C., Sridhar, K.R., Singh, R., Adholeya, A., Suryanarayanan, T.S., Rawat, S., Johri, B.N. (2006): Fungal biodiversity: Distribution, conservation and prospecting of fungi from India. - Current Science 89: 58-71.

[17] Mohanan, C. (2011): Macrofungi of Kerala. Handbook \# 27. Kerala Forest Research Institute, Peechi, India.

[18] Mueller, G.M., Schmit, J. P., Leacock, P.R., Buyck, B., Cifuentes, J., Desjardin, D.E., Halling, R,E., Hjortstam, K., Iturriaga, T., Larsson, K.-H., Lodge, D.J., May, T.W., Minter, D., Rajchenberg, M., Redhead, S.A., Ryvarden, L., Trappe, J.M., Walting, R., $\mathrm{Wu}, \mathrm{Q}$. (2007): Global diversity and distribution of macrofungi. - Biodiversity and Conservation 16: 37-48.

[19] Natarajan, K., Narayanan, K., Ravindran, C., Kumaresan, V. (2005a): Biodiversity of agarics from Nilgiri Biosphere Reserve, Western Ghats, India. - Current Science 88: 1890-1893.

[20] Natarajan, K., Senthilarasu, G., Kumaresan, V., Riviere, T. (2005b): Diversity in ectomycorrhizal fungi of a dipterocarp forest in Western Ghats. - Current Science 88: 1893-1895.

[21] Phillips, R. (2006): Mushrooms. - Pan Macmillan, London.

[22] Pielou, F.D. (1975): Ecological Diversity. - Wiley InterScience, New York.

[23] Sathe, A.V., Deshpande, S.D. (1980): Agaricales (mushrooms) of Maharashtra State. In: Sathe A.V. (ed.) Agaricales (Mushrooms) of South West India. Monograph \# 1, Part \# 1. pp. 1-66. Maharashtra Association of Cultivation of Science, Pune, India.

[24] Sathe, A.V., Daniel, J. (1980): Agaricales (mushrooms) of Kerala State. - In: Sathe, A.V. (ed.), Agaricales (Mushrooms) of South West India. Monograph \# 1, part \# 3. pp. 75-108. Maharashtra Association of Cultivation of Science, Pune, India.

[25] Swapna, S., Abrar, S., Krishnappa, M. (2008): Diversity of macrofungi in semi-evergreen and moist deciduous forest of Shimoga District, Karnataka, India. - Journal of Mycology and Plant Pathology 38: 21-26. 
[26] Tibuhwa, D.D. (2012): Termitomyces species from Tanzania, their cultural properties and unequalled basidiospores. - Journal of Biology and Life Science 3: 140-159.

[27] Tibuhwa, D.D., Kivaisi, A.K., Magingo F.S.S. (2010): Utility of the macromicromorphological characteristics used in classifying the species of Termitomyces. Tanzanian Journal of Science 36: 31-45. 


\section{APPENDIX}

Appendix 1. Occurrence of macrofungi (abundance of sporocarps $/ 625 \mathrm{~m}^{2}$ ) in four locations of the Western Ghats (RF, Reserve forest; SF, Shola forest; SG, Sacred grove; CAF, Coffee agroforest) during monsoon (June-September) and post-monsoon (October-November) season; new records for the Western Ghats are in bold-face); importance (Ed, edible; Me, medicinal; Em,ectomycorrhizal) and substrate preference (B, Bark; I, Insect; L, leaf litter; S, Soil; T, Twigs; W, Wood) are given for core-group fungi (MSF, mean sporocarps of a species/forest in a quadrat; MSM, mean sporocarps of a species/month in a quadrat; MS, mean sporocarps of a species per quadrat)

\begin{tabular}{|c|c|c|c|c|c|c|c|c|c|c|c|}
\hline \multirow[t]{3}{*}{ Macrofungus } & \multicolumn{10}{|c|}{ Sporocarps/quadrat } & \multirow{3}{*}{$\begin{array}{l}\text { Sporocarps/ } \\
\text { quadrat } \\
\text { (mean; } n=24 \text { ) } \\
\text { (MS) }\end{array}$} \\
\hline & \multicolumn{4}{|c|}{$\begin{array}{l}\text { Forest (mean; } n=6) \\
(\mathrm{MSF})\end{array}$} & \multicolumn{6}{|c|}{ Month (mean; $\mathrm{n}=4)(\mathrm{MSM})$} & \\
\hline & $\mathrm{RF}$ & SF & SG & CAF & Jun. & Jul. & Aug. & Sep. & Oct. & Nov. & \\
\hline Microporus vernicipes (Berk.) Kuntze $(\mathrm{T}, \mathrm{W})$ & 30.0 & 100.0 & - & - & 11.3 & - & - & 93.8 & 65.0 & 25.0 & 32.50 \\
\hline Pleurotus cornucopiae (Paulet) Rolland (B, W) (Ed) & - & - & 90.8 & - & - & - & 136.0 & - & - & - & 22.70 \\
\hline Trametes versicolor $(\mathrm{L}$.$) Lloyd (\mathrm{W})(\mathrm{Me})$ & 4.7 & - & - & 85.7 & - & 25.5 & 30.0 & 37.0 & 29.0 & 14.5 & 22.60 \\
\hline Schizophyllum commune $\mathrm{Fr} .(\mathrm{B}, \mathrm{W})(\mathrm{Me})$ & - & - & - & 60.0 & - & 5.0 & 17.5 & 30.0 & 20.0 & 17.5 & 15.00 \\
\hline Psathyrella lucipeta (Berk. \& Broome) Pegler & - & - & 58.3 & - & 87.5 & - & - & - & - & - & 14.60 \\
\hline Dacryopinax spathularia (Schwein.) G.W. Martin (B, W) & - & - & - & 50.0 & - & - & 50.0 & 25.0 & - & - & 12.50 \\
\hline Termitomyces microcarpus (Berk. \& Broome) R. Heim (S) (Ed) & - & 33.3 & - & 11.0 & - & - & - & 50.0 & - & 16.5 & 11.10 \\
\hline Xylaria multiplex (Kunze) Fr. & 44.0 & - & - & - & - & - & - & 50.0 & 11.0 & 5.0 & 11.10 \\
\hline
\end{tabular}


Xylaria longipes Nitschke (W) $(\mathrm{Me})$

Lentinus squarrosulus Mont. (W) (Ed)

Marasmius pellucidus Berk. \& Broome (T, W)

Xylaria filiformis (Alb. \& Schwein.) Fr. (L) (Me)

Ophiocordyceps nutans (Pat.) G.H. Sung, J.M. Sung, Hywel-

Jones \& Spatafora (I) (Me)

Marasmius guyanensis Mont. (L)

Phellinus pini (Brot.) Bondartsev \& Singer (B, W) (Me)

Cookeina tricholoma (Mont.) Kuntze (B, W)

Hypholoma subviride (Berk. \& M.A. Curtis) Dennis (B, W)

Phellinus gilvus (Schwein.) Pat. (B, W) (Me)

Boletinellus merulioides (Schwein.) Murrill (S) (Ed, Em)

Clavulinopsis laeticolor (Berk. \& M.A. Curtis) R.H. Petersen (S)

Royoporus spathulatus (Jungh.) A.B. De (B, W) (Ed)

Cyclomyces setiporus (Berk.) Pat. (W)

Auricularia auricula-judae (Bull.) Quél. (B, W) (Ed)

Hypholoma sp. (B, W)

Irpex lacteus $(\mathrm{Fr}.) \mathrm{Fr} .(\mathrm{B}, \mathrm{W})$

Stereum hirsutum (Willd.) Pers. (W)

Entoloma theekshnagandhum Manim., A.V. Joseph \& Leelav. (S)

(Em)

Amylosporus campbellii (Berk.) Ryvarden (W) (Ed)

Phellinus sp. (W)

Pleurotus djamor (Rumph. ex Fr.) Boedijn (B, W) (Ed)

Ganoderma oregonense Murrill (W) (Me)

Lenzites elegans (Spreng.) Pat. (W)

Pleurotus flabellatus Sacc. (B, W) (Ed)

\begin{tabular}{rrrr|rrrrrr|r}
4.7 & - & - & 26.0 & - & 11.3 & 14.0 & 7.5 & 12.0 & 1.3 & 7.68 \\
- & - & - & 27.7 & - & - & 22.1 & - & 14.0 & 5.9 & 6.93 \\
- & - & 27.0 & - & 40.5 & - & - & - & - & - & 6.75 \\
- & 25.0 & - & - & 37.5 & - & - & - & - & - & 6.25 \\
- & - & - & 22.2 & - & 17.0 & 16.3 & - & - & - & 5.55 \\
- & - & - & 22.0 & - & 14.3 & 7.4 & 11.3 & - & - & 5.50 \\
- & - & - & 21.7 & - & - & - & - & 13.0 & 20.0 & 5.43 \\
- & 20.9 & - & - & - & 20.0 & 11.4 & - & - & - & 5.23 \\
3.3 & - & 4.2 & 12.5 & - & 6.3 & 20.0 & 3.8 & - & - & 5.00 \\
20.0 & - & - & - & - & 25.0 & - & 2.3 & 1.0 & 1.9 & 5.00 \\
- & - & - & 19.7 & - & 14.5 & - & 15.0 & - & - & 4.93 \\
- & 18.1 & - & - & - & 26.3 & - & 0.8 & - & - & 4.53 \\
- & 13.3 & - & 2.0 & - & - & - & 2.5 & 21.0 & - & 3.83 \\
15.0 & - & - & - & - & - & - & 18.8 & 3.7 & - & 3.75 \\
- & - & - & 14.2 & - & 13.8 & 6.3 & 1.3 & - & - & 3.57 \\
14.0 & - & - & - & - & 21.3 & - & - & - & - & 3.55 \\
- & - & 14.2 & - & - & - & - & - & 16.0 & 5.0 & 3.55 \\
14.0 & - & - & - & - & - & - & - & 15.0 & 6.3 & 3.55 \\
- & 13.3 & 0.8 & - & 21.2 & - & - & - & - & - & 3.53 \\
13.0 & - & - & - & - & - & 20.0 & - & - & - & 3.33 \\
13.0 & - & - & - & - & - & - & 20.0 & - & - & 3.30 \\
- & 13.0 & - & - & - & - & 13.3 & 6.2 & - & - & 3.25 \\
13.0 & - & - & - & - & - & - & 6.3 & 7.5 & 5.0 & 3.13 \\
- & - & - & 12.5 & - & - & - & - & - & 18.8 & 3.13 \\
- & 11.2 & - & - & - & - & 11.8 & 5.0 & - & - & 2.80
\end{tabular}


Scutellinia setosa (Nees) Kuntze (B, L, W)

Inocybe viridiumbonata Pegler (S) (Em)

Inonotus sp. (W)

Coprinopsis fibrillosa (Berk. \& Broome) Redhead, Vilgalys \&

Moncalvo (B)

Xylaria polymorpha (Pers.) Grev.

Ganoderma lucidum (Curtis) P. Karst.

Ganoderma applanatum (Pers.) Pat.

Marasmiellus ramealis (Bull.) Singer (B, T)

Favolaschia tonkinensis (Pat.) Kuntze

Filoboletus manipularis (Berk.) Singer (B, T, W) (Ed)

Crepidotus sp.

Marasmius kuthubutheeni Y.S. Tan, Desjardin, Vikinesw. \& N.

Abdullah

Chondrostereum purpureum (Pers.) Pouzar

Coriolopsis telfari (Klotzsch) Ryvarden

Oxyporus cervinogilvus (Jungh.) Ryvarden

Podosordaria elephanti J.D. Rogers \& Y.M. Ju

\section{Pluteus sp. 1}

Ascocoryne cylichnium (Tul.) Korf

Termitomyces heimii Natarajan

Conocybe pubescens (Gillet) Kühner

\section{Lactarius sp.}

\section{Agaricus sp.}

Coprinus micaceus (Bull.) Fr.

Marasmius rotula (Scop.) Fr.

Pholiota squarrosa (Vahl) P. Kumm.

\begin{tabular}{|c|c|c|c|c|c|c|c|c|c|c|}
\hline- & - & - & 10.8 & - & - & - & 13.8 & 2.5 & - & 2.70 \\
\hline- & - & 10.0 & - & - & - & - & 15.0 & - & - & 2.50 \\
\hline 9.2 & - & - & - & - & - & - & 13.8 & - & - & 2.30 \\
\hline- & - & - & 8.3 & - & - & - & - & - & 12.5 & 2.08 \\
\hline- & 8.3 & - & - & - & - & - & 6.8 & 2.9 & 0.7 & 2.08 \\
\hline- & - & 7.5 & 0.7 & - & - & - & 3.5 & 3.8 & 5.0 & 2.05 \\
\hline- & - & 7.7 & - & - & - & - & 2.6 & 9.0 & - & 1.93 \\
\hline- & - & - & 7.5 & 11.3 & - & - & - & - & - & 1.88 \\
\hline- & - & - & 7.2 & - & - & - & 10.8 & - & - & 1.80 \\
\hline- & - & - & 7.2 & 10.8 & - & - & - & - & - & 1.80 \\
\hline 6.7 & - & - & - & 10.1 & - & - & - & - & - & 1.68 \\
\hline- & - & - & 6.7 & - & 5.0 & - & 5.1 & - & - & 1.68 \\
\hline 5.8 & - & - & - & - & - & - & - & 8.8 & - & 1.45 \\
\hline- & - & - & 5.8 & - & - & - & - & - & 8.7 & 1.45 \\
\hline 5.8 & - & - & - & - & - & - & - & - & 8.7 & 1.45 \\
\hline 5.8 & - & - & - & - & 8.7 & - & - & - & - & 1.45 \\
\hline- & - & - & 5.7 & 1.4 & 7.2 & - & - & - & - & 1.43 \\
\hline 5.5 & - & - & - & 8.3 & - & - & - & - & - & 1.38 \\
\hline 5.0 & - & - & - & - & - & 7.5 & - & - & - & 1.25 \\
\hline 0.7 & - & - & - & - & 1.1 & - & - & - & - & 1.18 \\
\hline- & 4.7 & - & - & 7.1 & - & - & - & - & - & 1.18 \\
\hline 0.2 & - & - & 4.2 & 6.3 & - & 0.3 & - & - & - & 1.10 \\
\hline- & - & - & 4.2 & - & - & 6.3 & - & - & - & 1.05 \\
\hline - & 4.2 & - & - & 6.3 & - & - & - & - & - & 1.05 \\
\hline 4.2 & - & - & - & - & - & - & 6.3 & - & - & 1.05 \\
\hline
\end{tabular}

APPLIED ECOLOGY AND ENVIRONMENTAL RESEARCH 14(2): 1-21. http://www.aloki.hu • ISSN 15891623 (Print) • ISSN 17850037 (Online) DOI: http://dx.doi.org/10.15666/aeer/1402_001021 
Termitomyces eurrhizus (Berk.) R. Heim

Entoloma haematinum Manim., Leelav. \& Noordel.

Phellinus chrysoloma (Fr.) Donk

\section{Pleurotus sp. 1}

\section{Ascocoryne sp. 2}

Auricularia mesenterica (Dicks.) Pers.

Termitomyces clypeatus R. Heim

\section{Inocybe sp.}

Crepidotus mollis (Schaeff.) Staude

Hygrocybe conica (Schaeff.) P. Kumm.

Hexagonia tenuis Speg.

Lenzites betulina (L.) Fr.

Marasmius trichotus Corner

Clitocybe pallida Velen.

Gloiocephala resinopunctata Manim. \& K.A. Thomas

Gymnopilus dilepis (Berk. \& Broome) Singer

\section{Nigroporus sp.}

Oxyporus sp.

Pleurotus eous (Berk.) Sacc.

Ramariopsis kunzei (Fr.) Corner

Coprinus leiocephalus P.D. Orton

Nigroporus vinosus (Berk.) Murrill

Daldinia concentrica (Bolton) Ces. \& De Not.

\section{Fomitopsis sp.}

Xylaria escharoidea (Berk.) Sacc.

Laetiporus sulphureus (Bull.) Murrill

Pleurotus sp. 2

\begin{tabular}{rrrr|rrrrrrr}
2.2 & - & 1.8 & - & 3.3 & 2.3 & 0.5 & - & - & - & 0 \\
3.8 & - & - & - & 5.7 & - & - & - & - & - & 1.00 \\
- & - & - & 3.7 & - & - & - & - & 2.8 & 2.8 & 0.95 \\
3.7 & - & - & - & - & 2.7 & - & 2.9 & - & - & 0.93 \\
3.3 & - & - & - & 5.0 & - & - & - & - & - & 0.93 \\
- & - & - & 3.3 & - & 5.0 & - & - & - & - & 0.83 \\
- & - & - & 3.3 & - & 3.8 & 1.2 & - & - & - & 0.83 \\
- & - & 3.0 & - & 4.5 & - & - & - & - & - & 0.83 \\
- & - & 2.9 & - & - & - & - & 4.4 & - & - & 0.75 \\
2.8 & - & - & - & 4.2 & - & - & - & - & - & 0.73 \\
- & - & - & 2.7 & - & - & - & - & 1.6 & 2.5 & 0.70 \\
- & - & - & 2.7 & - & - & - & 4.1 & - & - & 0.68 \\
- & - & 2.7 & - & 4.1 & - & - & - & - & - & 0.68 \\
- & - & - & 2.5 & 3.8 & - & - & - & - & - & 0.68 \\
- & 2.5 & - & - & - & - & 3.8 & - & - & - & 0.63 \\
- & - & - & 2.5 & - & - & - & 3.8 & - & - & 0.63 \\
2.5 & - & - & - & - & - & - & - & - & 3.8 & 0.63 \\
- & 2.5 & - & - & - & - & - & - & 3.8 & - & 0.63 \\
- & 2.5 & - & - & - & - & 3.8 & - & - & - & 0.63 \\
- & 1.7 & 0.8 & - & 1.3 & 2.5 & - & - & - & - & 0.63 \\
- & - & - & 2.2 & - & - & 3.3 & - & - & - & 0.63 \\
- & 2.2 & - & - & - & - & - & 3.3 & - & - & 0.55 \\
- & - & - & 2.0 & - & 3.0 & - & - & - & - & 0.55 \\
- & - & - & - & - & - & - & 3.0 & - & - & 0.50 \\
- & 2.0 & - & - & - & - & - & 3.0 & - & - & 0.50 \\
- & - & - & 1.8 & - & - & - & - & 2.7 & - & 0.50 \\
- & - & 1.7 & - & - & - & 2.6 & - & - & - & 0.45 \\
& & & & & & & & & & 0.43
\end{tabular}

APPLIED ECOLOGY AND ENVIRONMENTAL RESEARCH 14(2): 1-2 http://www.aloki.hu • ISSN 15891623 (Print) • ISSN 17850037 (Online) DOI: http://dx.doi.org/10.15666/aeer/1402_001021

\subsection{0}

0.95

0.93

0.83

0.83

0.75

0.73

0.70

0.68

0.68

0.63

0.63

0.63

0.63

0.63

0.55

0.50

0.50

.45 
Scleroderma sp. 3

Amauroderma sp.

Irpex sp.

Lepiota metabola (Berk. \& Broome) Sacc.

Scleroderma areolatum Ehrenb.

\section{Scleroderma sp. 1}

\section{Ascocoryne sp. 1}

Geastrum saccatum $\mathrm{Fr}$.

Lepiota phlyctaenodes (Berk. \& Broome) Sacc.

Lepiota thrombophora (Berk. \& Broome) Sacc.

Merulius tremellosus Schrad.

\section{Scleroderma sp. 2}

Aleuria rubra L.R. Batra

Entoloma vernum $\mathrm{S}$. Lundell

Gymnopilus subbellulus Hesler

Hygrocybe alwisii (Berk. \& Broome) Pegler

Lentinus dicholamellatus Manim.

Phaeolus schweinitzii (Fr.) Pat.

Phlebopus portentosus (Berk. \& Broome) Boedij

Trogia infundibuliformis Berk. \& Broome

Amanita sp. 2

Cookeina indica Pfister \& R. Kaushal

Lepiota erythrogramma (Berk. \& Broome) Sacc.

Ramaria gracilis (Pers.) Quél.

Panus sp.

Polyporus arcularius Lázaro Ibiza

Gymnopus sp. 1

\begin{tabular}{|c|c|c|c|c|c|c|c|c|c|c|}
\hline 1.7 & - & - & - & - & 2.6 & - & - & - & - & 0.43 \\
\hline 1.7 & - & - & - & 2.6 & - & - & - & - & - & 0.43 \\
\hline- & 1.5 & - & - & - & - & - & - & 2.3 & - & 0.38 \\
\hline 1.5 & - & - & - & 2.3 & - & - & - & - & - & 0.38 \\
\hline- & - & 1.5 & - & 2.3 & - & - & - & - & - & 0.38 \\
\hline- & - & 1.5 & - & 0.5 & - & 1.5 & 0.3 & - & - & 0.38 \\
\hline 1.3 & - & - & - & 2.0 & - & - & - & - & - & 0.33 \\
\hline- & - & - & 1.3 & - & - & 2.0 & - & - & - & 0.33 \\
\hline- & 1.3 & - & - & 2.0 & - & - & - & - & - & 0.33 \\
\hline- & - & - & 1.3 & 2.0 & - & - & - & - & - & 0.33 \\
\hline- & 1.3 & - & - & 1.2 & 0.8 & - & - & - & - & 0.33 \\
\hline- & - & 1.3 & - & - & 2.0 & - & - & - & - & 0.33 \\
\hline- & - & - & 1.2 & - & - & 1.8 & - & - & - & 0.30 \\
\hline- & 1.2 & - & - & - & 1.8 & - & - & - & - & 0.30 \\
\hline- & 1.2 & - & - & - & - & 1.8 & - & - & - & 0.30 \\
\hline- & - & 1.2 & - & - & - & 1.8 & - & - & - & 0.30 \\
\hline 1.2 & - & - & - & 1.8 & - & - & - & - & - & 0.30 \\
\hline- & - & 1.2 & - & - & - & - & 1.0 & 0.8 & - & 0.30 \\
\hline- & - & - & 1.2 & 0.5 & - & 0.5 & 0.8 & - & - & 0.30 \\
\hline- & - & - & 1.2 & 1.8 & - & - & - & - & - & 0.30 \\
\hline- & - & - & 1.0 & 1.5 & - & - & - & - & - & 0.25 \\
\hline- & 1.0 & - & - & - & 1.5 & - & - & - & - & 0.25 \\
\hline- & - & 1.0 & - & 1.5 & - & - & - & - & - & 0.25 \\
\hline- & - & 1.0 & - & - & - & 1.5 & - & - & - & 0.25 \\
\hline- & 1.0 & - & - & - & 1.5 & - & - & - & - & 0.25 \\
\hline- & - & - & 1.0 & - & - & 1.5 & - & - & - & 0.25 \\
\hline- & - & 0.9 & - & 1.0 & - & - & 0.4 & - & - & 0.23 \\
\hline
\end{tabular}


Panus conchatus (Bull.) Fr.

Piloporia indica Ganesh \& Ryvarden

Postia stiptica (Pers.) Jülich

Psilocybe fimetaria (P.D. Orton) Watling

Clavulinopsis aurantiocinnabarina (Schwein.) Corner

Coprinus cinereus (Schaeff.) Gray

Coprinus patouillardii Quél.

Lysurus brahmagirii C. Mohanan

\section{Marasmiellus sp.}

Panaeolus fimicola (Pers.) Gillet

Psilocybe coprophila (Bull.) P. Kumm.

Trametes maxima (Mont.) A. David \& Rajchenb.

Xylaria symploci A. Pande, Waingankar, Punekar \& Randive

Agaricus caribaeus Pegler

Clavulinopsis luteoalba (Rea) Corner

\section{Entoloma sp.}

Oudemansiella canarii (Jungh.) Höhn.

Ramaria flava (Schaeff.) Quél.

Ramariopsis pulchella (Boud.) Corner

\section{Tricholoma sp.}

\section{Amanita sp. 1}

Boletus huronensis A.H. Sm. \& Thiers

Geastrum fimbriatum Fr.

Geastrum sp.

Lepiota plumbicolor (Berk. \& Broome) Sacc.

Lycoperdon nigrescens Pers.

\section{Pholiota sp.}

\begin{tabular}{rrrr|rrrrrrr|}
- & 0.8 & - & - & 1.2 & - & - & - & - & - & 0.20 \\
0.8 & - & - & - & - & - & - & - & 1.2 & - & 0.20 \\
- & - & - & 0.8 & - & - & 1.2 & - & - & - & 0.20 \\
- & 0.8 & - & - & - & - & - & - & 1.2 & - & 0.20 \\
- & 0.5 & 0.2 & - & - & 1.1 & - & - & - & - & 0.18 \\
0.7 & - & - & - & - & 1.1 & - & - & - & - & 0.18 \\
- & 0.7 & - & - & - & - & - & - & 1.1 & - & 0.18 \\
- & - & - & 0.7 & - & - & 1.0 & 0.1 & - & - & 0.18 \\
- & - & - & 0.7 & 1.1 & - & - & - & - & - & 0.18 \\
- & 0.7 & - & - & - & - & - & - & 1.1 & - & 0.18 \\
- & 0.7 & - & - & - & 1.1 & - & - & - & - & 0.18 \\
- & 0.7 & - & - & - & - & - & - & 1.1 & - & 0.18 \\
0.7 & - & - & - & - & 1.1 & - & - & - & - & 0.18 \\
- & - & 0.3 & 0.2 & 0.5 & - & - & 0.3 & - & - & 0.13 \\
- & - & 0.5 & - & - & - & - & - & - & 0.8 & 0.13 \\
- & - & 0.5 & - & - & - & - & 0.8 & - & - & 0.13 \\
- & - & 0.5 & - & - & - & - & - & 0.8 & - & 0.13 \\
- & 0.5 & - & - & - & - & 0.8 & - & - & - & 0.13 \\
- & 0.5 & - & - & - & 0.8 & - & - & - & - & 0.13 \\
- & - & - & 0.5 & - & 0.8 & - & - & - & - & 0.13 \\
- & - & - & 0.3 & 0.5 & - & - & - & - & - & 0.08 \\
- & - & 0.3 & - & - & 0.5 & - & - & - & - & 0.08 \\
- & - & 0.3 & - & - & 0.5 & - & - & - & - & 0.08 \\
0.3 & - & - & - & - & - & 0.5 & - & - & - & 0.08 \\
- & - & - & 0.3 & - & - & 0.5 & - & - & - & 0.08 \\
- & 0.3 & - & - & 0.5 & - & - & - & - & - & 0.08 \\
- & 0.3 & - & - & 0.5 & - & - & - & - & - & 0.08
\end{tabular}


Xerula furfuracea (Peck) Redhead, Ginns \& Shoemaker

Amauroderma rugosum (Blume \& T. Nees) Torrend

Clitocybe minuta C. Mohanan

Cystoagaricus trisulphuratus (Berk.) Singer

Dictyophora cinnabarina W.S. Lee

Geastrum pseudostriatum Hollós

Hericium erinaceum Hesler

Lycoperdon utriforme Bull.

Lepista sp.

Phellinus rimosus (Berk.) Pilát

Russula aciculocystis Kauffman ex Bills \& O.K. Mill.

Termitomyces tylerianus Otieno

\begin{tabular}{|c|c|c|c|c|c|c|c|c|c|}
\hline- & 0.3 & - & - & - & 0.5 & - & - & - & 0.08 \\
\hline 0.2 & - & - & 0.3 & - & - & - & - & - & 0.05 \\
\hline- & 0.2 & - & - & - & - & 0.3 & - & - & 0.05 \\
\hline- & 0.2 & - & 0.3 & - & - & - & - & - & 0.05 \\
\hline 0.2 & - & - & 0.3 & - & - & - & - & - & 0.05 \\
\hline- & 0.2 & - & - & - & 0.3 & - & - & - & 0.05 \\
\hline .2 & - & - & - & 0.3 & - & - & - & - & 0.05 \\
\hline- & - & 0.2 & 0.3 & - & - & - & - & - & 0.05 \\
\hline- & 0.2 & - & - & - & 0.3 & - & - & - & 0.05 \\
\hline- & 0.2 & - & - & - & - & - & 0.3 & - & 0.05 \\
\hline - & - & - & 0.3 & - & - & - & - & - & 0.05 \\
\hline- & - & - & - & 0.3 & - & - & - & - & 0.05 \\
\hline
\end{tabular}

